\title{
Social and economic efficiency of development and use of alternative power energy
}

\author{
Yuriy Borovik ${ }^{1 *}$, Yuriy Yelagin ${ }^{1}$, Natalia Gritsenko ${ }^{1}$, Nikolay Kondratyuk ${ }^{1}$ \\ and Vladimir Nakonechniy ${ }^{2}$ \\ ${ }^{1}$ Ph.D. in Economics, Ukrainian State University of Railway Transport, Ukraine \\ 2 Doctor of Science in State Administration, Department of Economics and \\ International Relations of Kharkov Regional State Administration
}

\begin{abstract}
Annotation. Research has been performed on the state of development and trends for alternative energy sources. Advantages and disadvantages of renewable energy have been considered. Main types of the effects due to the implementation of renewable energy sources have been investigated. Main aspects of the actual effects upon society as a whole have been determined, in order to perform the objective assessment of the social efficiency of implementation of renewable energy sources. Methods to determine the social and economic efficiency of using the renewable energy sources have been suggested.
\end{abstract}

\section{Problem statement}

The depletion of traditional energy sources, growing negative impact of power engineering upon environment, as well as the increased environmental requirements, significant fluctuations in energy prices, trends for increasing energy and economic security, political character of energy supply and another related factors caused the revision of the current state of the sector of power engineering and search for the opportunities to update and "reset" it.

In the course of its activities, Ukrainian alternative power engineering has been based upon a series of Acts and Resolutions of the Cabinet of Ministers of Ukraine [1-5].

The availability of energy resources has been traditionally considered as one of the main indicators of the energy security of a certain country. The development of renewable power engineering all over the world has been caused by two kinds of global circumstances: limited character of the world energy reserves and insufficient availability of organic fuel reserves, along with the dependence of majority of the countries on fuel import operations; as well as significant negative impact of traditional (fuel) energy supply upon environment and nature [6].

*Corresponding author: ytbx@ukr.net 
According to the data presented by the State Agency on Energy Efficiency of Ukraine, during the first six months of 2018, they installed the energy generating facilities for about $270 \mathrm{MW}$ in electrical capacity, based upon the renewable energy sources (RES) according to the "green" tariff in Ukraine. This amount exceeds the double amount in the first halfyear period in 2017 (127 MW), and it overcomes the capacity of the installed facilities for the whole year 2017 (257 MW). However, as per the total power generation amount in Ukraine, the share of renewable energy sources still remains insignificant $(1,644 \mathrm{MW})$ and it slightly exceeds the amount of $1.2 \%$ of the total capacity of power generation. Nowadays, nuclear and thermal power engineering facilities are mainly operated in the country [7].

It goes without saying that renewable energy sources can never replace the solid fossil fuels completely, though their use will provide a huge positive economic and energy effect, as well as guarantee its social impact. Therefore, further research work related to the state of development in the sectors of the alternative energy sources in Ukraine, the issue to overcome the energy dependence of our country and the study of the social and economic efficiency by means of creating a "pool" of alternative energy sources are the core subjects of development of the national economy.

\section{Review of the Recent Studies and Published Works.}

Considering the problems of development of alternative power energy, in particular, we refer to the aspects of feasibility study of the projects using renewable energy sources, assessment of their competitiveness based on traditional energy systems and the prospects for their implementation have been presented in the works by such researchers as A. Galchinsky, G. Geletukha, T. Zheleznaya, G. Zabarnyi, S. Kudrya, A. Prokop, G. Sytnik, A. Sukhodolya and others. Such foreign scientists as V. Weiss, G. Erdmann, M. Ragwitz, P. Samuelson, G. Scheer, I. Schumpeter, V. Streicher and many others investigated the issues of energy saving, development and state support of alternative power energy. The researcher B. Savenko suggested the environmental and economic assessment of the efficiency of using the alternative energy sources [8].

However, yet notwithstanding the significant scientific contribution to research and development of the above-mentioned problem, the issues of social and economic efficiency and the balanced use of alternative energy sources, in particular, in the context of political instability and energy dependence of the country, still remain the core subjects and enhance the actual and urgent character of the further scientific research in this field.

\section{Problem Statement.}

The purpose of the study is to provide certain more profound methodological approaches to the social and economic efficiency of using alternative energy sources.

\section{Presentation of Principal Research Materials.}

The requirement to implement a high priority policy related to the energy saving issues has been mainly associated with a shortage of own fuel and energy resources in the country, dependence on the gas and oil exporting countries, growing extracting costs, as well as global environmental issues.

Speaking about the importance of formulation of the energy development strategy in order to provide the sustainable development of society, we should underline that energy production affects such sectors as health and life of people, provision of sustainable 
development of settlements, protection of atmospheric and biospheric environment, rational use of natural and energy resources.

Renewable electricity production has the following advantages:

- inexhaustibility of resources;

- absence of extra carbon dioxide emissions;

- absence of harmful emissions;

- keeping the thermal balance of the Planet;

- availability of resources (sun, wind) to use;

- option of using lands not suggested for economic purposes (installation of solar and wind facilities);

- absence of any need for water (solar and wind power stations).

Meanwhile, using the renewable energy sources also has some disadvantages:

- low density of energy;

- unstable and "probabilistic" nature of energy supply (sun and wind resources);

- need for accumulation and reservation of electric power (sun and wind resources);

- absence of developed industry and lack of wind energy infrastructure in Ukraine;

- flooding of fertile lands and local climate alterations (large hydroelectric power plants).

The global advantage of renewable energy over the traditional fuel energy is that using fuel and application of the related fuel costs are not required. This concept can help both reduce the fuel dependence of the electric power industry and decrease the negative impact of fuel energy production upon the atmosphere of Earth and environment where the humans live.

The main types of effects from due to the introduction of renewable energy sources (RES) are considered to be economic and environmental factors. The economic effect is determined in monetary value as the difference between the benefits received and the costs incurred, taking into account the related discounting of such values. The resulting difference ratio is called the profit or the economic effect of the project performance.

Speaking about the efficiency, according to the key concept of any social and economic activity, the focus is traditionally made on economic efficiency; its concentrated value is associated with the "costs vs. effects" ratio. Since nowadays any public activity has been performed using the continuously increasing amount of the limited resources, the approach should be similar to that economic activity.

However, any economic activity is social by its nature, thus, the so-called "social efficiency" requires research, accounting and assessment.

The problem of assessing the impact of power energy upon the environment and society is directly connected with the measurement of external costs. The external costs mean the incidental costs related to the manufacturing of the goods and services that are not borne by producers and consumers, but incurred by the population and society as a whole, without any eventual reimbursement.

It should be noted that while performing the comparative analysis within the framework of feasibility study of financing the development of any particular type of electrical power production for society, we should consider not only the investments into the infrastructure of power engineering sector, but the estimated costs and effects for the whole society as well. The effects of using the renewable energy received by the society mean the social effects that help us solve the actual social and economic task - i.e. improving the living standards and quality of life of the population. 
Nevertheless, while realization of the "green" economy principles and implementing the alternative energy sources for the purposes of energy saving, we believe that only economic and environmental indicators should be emphasized. The resulting social effect due to the use of renewable energy sources could become a significant incentive, in order to promote the concept of "green" economy on the regional level. When preparing the investment project authorization for renewable energy production, special attention should be paid to the social efficiency resulting from their implementation. In case of using the renewable energy sources (RES), the social effect would reflect the option to solve the urgent social and economic task - i.e. improving the living standards and quality of life of the population.

The assessment of social efficiency, unlike the eventual economic and environmental efficiency, is rather a less studied issue, because they haven't developed a consistent approach to its definition until nowadays. Making the assessment of social effect in monetary values and natural items incur considerable hardships for economists. Anyway, the estimated social efficiency should be taken into consideration, while implementing the measures related to the "green" energy.

The social effect of the implementation of investment projects has been divided into its direct and indirect types. The direct effect is related to the construction, reconstruction, modernization and further operation of the designed facilities. The indirect effect can be estimated in the form of tax revenues, additional investments for the project realization. The investments in a particular project can stimulate the additional increase in investments within the various sectors of domestic economy. Thus, the social effect of implementation of the renewable energy sources (RES) would be interpreted as a value to be obtained on the basis of identification and economic evaluation of qualitative characteristics that affect the social changes.

In order to perform the objective assessment of the social efficiency of implementation of renewable energy sources, first of all it is necessary to identify the main sector where the effects could be obtained for society as a whole.

The social effects of renewable energy mean those which the society receives while using the renewable energy in comparison with the traditional fuel energy.

We identified the main effects of renewable energy upon society in the following areas:

- environmental effects mean the actual effects of reducing the costs related to elimination of influence of power industry upon atmosphere and biosphere.

- effects of protecting the human life and health mean the actual effects of reducing the costs of protecting life and health from the impact of activities of the energy enterprises, which deal with the renewable energy, in comparison to the fuel energy, respectively.

- the infrastructure effects mean the actual effects of reducing the costs of society related to maintenance and operation of the infrastructure applied for the extraction of fuel raw materials, its preservation, delivery to electric power plants and disposal of wastes of the fuel power production.

The assessment of efficiency to protect human life and health, unlike the eventual economic and environmental efficiency, does not have a consistent approach and definition methodology.

The social effect of protection of human life and health means reduction of the incidence of population, improving their work and rest conditions, improving people's health; thus, it incurs a number of social effects: savings in social insurance assents and treatment costs for patients. In general, the social effect of protection the human health can be determined through such economic indicators:

- effect of reduction in payments from the Social Insurance Fund (under a sick leave certificate), as related to the incidence of population due to environmental pollution by the power energy enterprises; 
- effect of reduction in payments for treatment of the population due to the same abovementioned reasons;

- effect of increasing working capacity and income level due to the normalization of social and environmental situation.

Thus, the social efficiency of protection of human life and health means that very part of social efficiency, which reflects the cost effectiveness related to improving the human living conditions.

The society receives a long-term economic effect through investing into the development of power energy infrastructure which involves low external costs.

\section{Conclusions.}

While implementing the energy sector development strategy and the related feasibility study of investments into the projects for the further implementation of alternative energy sources, not only financial and environmental performance factors should be emphasized.

Ukraine has a sufficient renewable energy potential, it could completely satisfy the eventual demand for energy resources and services, even in case of maintaining a high proportion of energy-intensive industries (such as metallurgical engineering, chemical industry, etc.) in the country. The domestic production of structural elements required for the technological equipment for alternative power engineering in Ukraine should be arranged; it will help solve not only the issues related to the energy and economic sectors, but it would also provide a program for the development of socially efficient energy infrastructure within the country.

\section{References}

1. Law of Ukraine “On Power Engineering” dd. October, 161997 № 575/97-VR, as amended. Available at: $\underline{\mathrm{http}}$ ///kodeksy.com.ua/pro elektroenergetiku.htm

2. Law of Ukraine “On Energy Saving” dd. October, 162012 № 5463-VI, as amended.Available at: http://zakon2.rada.gov.ua.

3. Law of Ukraine "On Alternative Energy Sources" dd. February, 202003 № 555-IV, as amended. Available at: http: //kodeksy.com.ua/pro_al_ternativni_dzherela_energiyi.htm

4. Resolution of the Cabinet of Ministers of Ukraine dd. October 05,2004 No. 1307 "On Procedure of Issue a Certificate for Fuel being Classified as the Alternative Source", as amended. Available at: https://zakon.rada.gov.ua/laws/show/1307-2004-\%D0\%BF

5. Resolution of the Cabinet of Ministers of Ukraine dd. August, 182017 № 605-r "On Approval of Energy Strategy of Ukraine until year 2035 - Safety, Energy Efficiency, Competitiveness" Available at: https://zakon.rada.gov.ua/laws/show/605-2017$\% \mathrm{D} 1 \% 80 \#$ n6

6. Yu.T. Borovik, Yu. V. Yelagin. Bulletin of Economy of Transport and Industry. 61, 103-110 (2018).

7. Scientific and Manufacturing Enterprise "VD MAIS", website. Available at: http://vdmais.ua/rynochnye-trendy-alternativnaya-energetika-ukrainy-v-2018-godu

8. B.V. Savenko. Environmental Safety. 1, 136-142 (2017).

9. "Transitional Stage for Ukraine to Come to Renewable Energy before year 2050" / O. Dyachuk, M. Chepelev, R. Podolets, G. Tripolska, et al.; under general editorship of Yu. Ogarenko and O. Aliyeva. Representative Office of G. Boll in Ukraine. - Kyiv: Publishing House “ART BOOK” LLC, 88 (2017). 
10. Energy Efficiency and its contribution to energy security and the 2030 Framework for climate and energy policy. Available at: https://ec.europa.eu/energy/sites/ener /files/documents/2014_eec_communication_adopted_0.pdf. 